\title{
Perencanaan Humas Dan Usaha Membangun Citra Lembaga Yang Unggul
}

\author{
Slamet Mulyadi \\ Universitas Nurul Jadid \\ smulyadi2608@gmail.com
}

\begin{abstract}
Public relations, commonly called public relations, are key players in the relationship between educational institutions and the public or the public. Because be is a communication link between the two. Public relation has been spread in various agencies both the government and its parts (police, meliter, and so on), organizations, boarding schools, foundations, educational institutions and others. but whether it is already running as the public relations in management know just the name. In the discussion of the task of these public relations planning models the author uses argumentative descriptive methods. That is describing public relations planning models with reviews that can be accounted for. Supported by several studies in published journals on public relations planning model, this journal presents findings that can help in developing educational institutions bususnnya part of public relations. From this descriptive method of argumentative research, the problem encountered is that most educational institutions do not function public relations as management. public relations are only complementary and there are only important subjects. therefore the offer from this article how public relations or public relations provides an overview of how public relations are functioned and executed. As a liaison anntara within its own internal institutions and institutions with the public. public relations acts as a synergistic part, between institutions and the public both benefit or take and give. Hopefully useful, amen.
\end{abstract}

Keywords: Planning, Public Relations, Institutional Image

\begin{abstract}
Abstrak : Publik relation, biasa di sebut humas, merupakan pemain kunci didalam bubungan antara lembaga pendidikan dan masyarakat atau publik. Sebab ia adalah penyambung komunikasi diantara keduanya. Publike relation ini sudah menyebar di berbagai instansi baik itu pemerintahan dan bagianbagiannya (kepolisian, meliter, dan lain sebagainya), organisasi, pesantren, yayasan, lembaga pendidikan dan lain sebaginya. namun apakah sudab berjalan sebagaimana publik relation dalam menejemen tau banya sekedar ada namanya saja. Dilam pembahasan tugas model-model perencanaan publik relation ini penulis menggunakan metode deskSriptif argumentatif. Yaitu menggambarkan model-model perencanaan publik relation dengan ulasan yang bisa di pertanggung jawabkan. Di dukung beberapa penilitian yang terdapat didalam jurnal-jurnal yang telah di terbitkan mengenai model perencanaan publik relation, jurnal ini menyugubkan temuan-temuan yang bisa membantu dalam mengembangkan lembaga pendidikan bususnnya bagian kehumasan. Dari metode penelitian deskriptif argumentatif ini masalah yang di jumpai adalab kebanyakan lembaga pendidikan tidak memfungsikan publik relation sebagai menejemen. publik. relation hanya menjadi pelengkap dan adanya hanya pokok yang penting ada. maka dari itu tawaran dari tulisan ini bagaimana publik relation atau bumas memberikan gambaran bagimana publik relation di fungsikan dan dijalankan. Sebagai penghubung anntara didalam lembaga internal sendiri dan lembaga dengan publik. publik relation berperan sebagai bagian yang sinergis, antara lembaga dan publik samasama diuntungkan atau take and give. Mudah mudahan bermanfaat,amin.
\end{abstract}

Kata Kunci : Perencanaan, Humas, Citra Lembaga

\section{Pendahuluan}

Perencanaan adalah langkah awal sebagai patokan lembaga untuk tercapainya sebuah tujuan organisasi . Setiap organisasi maju perencanaan sangat diperhitungkan secara matang baik itu negara, perusahaan maupun lembaga. Ambillah contoh negara-negara yang menganut demokrasi seperti amerika, prancis, inggris di masa masa kampanyenya setiap kandidat sudah menawarkan visi dan misi mereka sebagai gambaran tentang bagaimana 
neganya mau dijalankan. Di perusahaan terkenalpun seperti halnya microsof, samsung, aple, ferrari juga memiliki perencanaan yang matang bahkan mereka sampai menyewa perusahaan publik relation ternama.

Di negara indonesia sejak masa orde lama sampai masa reformasi sudah menerapkan perencanaan atau planning. Masa orde lama, soekarno mempunyai planning negara indonesa yang di gariskan dalam tap MPRS. Masa orde baru merencanakan pembangunannya melalui pola umum pembangunan jangka panjang, pelita 1 pelita 2 pelita 3 dan seterusnya demikian juga kampanye maupun ketika sudah terpilih pasti memiliki rencana-rencana yang mau ditempuh dalam jangka panjang, menengah, maupun jangka pendek. Hal itu untuk memberi gambaran awal bagaimana indonesia kedepan.

Perencanaan juga diterapkan didalam sebuah lembaga pendidikan. ${ }^{1}$ Lembaga pendidikan mempunyai acuan awal untuk membangun, menuju, dan melangkah ke lembaga yang di impikan. Setiap departemen dan bagian bagian sudah mempunya beberapa progam perencanaan baik itu bagian kurikulum, sarana dan pra sarana, kesiswaan dan lain sebagainya, termasuk didalamnya adalah humas. Bidang ini mempunyai peran krusial dalam memajuakan sebuah lembaga. Namun bagian ini masih di pandang sebelah mata di banyak lembaga pendidikan.

Banyak lembaga pendidikan yang menyepelekan bagian humas. menganggapnya humas itu hanya sebagai pelengkap, strukturnya hanya sebagai pajangan dan atau melengkapinya hanya karena saran dari pemerintah. Padahal bidang ini adalah penyembung antara sekolah dengan masyarakat, bagia ini juga bisa Memecahkan persoalan persoalan internal sekolah, mengetahui kebutuhan dan tuntutan kebutuhan masyarakatpun pasti lewat bagian humas ini, bahkan bagian humas ini adalah ruh pendidikan. Public relations merupakan sebagai perantara antara pimpinan organisasi dengan publiknya. Baik dalam upaya membina hubungan masyarakat internal, maupun eksternal. ${ }^{2}$

Disamping itu humas merupakan sebuah seni sekaligus ilmu sosial dalam menganalisa kecenderungan, mampu meramalkan konsekuensinya, dan memberikan pengarahan kepada pimpinan lembaga serta melaksanakan program-program terencana yang bisa memenuhi kepentingan baik institusi maupun lembaga tersebut serta masyarakat yang terkait. ${ }^{3}$

\footnotetext{
${ }^{1}$ Hasan Baharun and Syafiqiyah Adhimiy, 'Curriculum Development Through Creative Lesson Plan', Cendekia: Jurnal Kependidikan Dan Kemasyarakatan, 16.1 (2018), 41-62.

${ }^{2}$ Walter K Lindenmann, 'Public Relations Research for Planning and Evaluation Resource', Institute for Public Relations, 2006, 1-33.

${ }^{3}$ Manap Somantri, Perencanaan Pendidikan, 2014.
} 
Di dalam humas perlu adanya perencanaan -perencanaan yang merupakan langkah awal merealisasikan tujuan lembaga, Seperti analisis swot, perumusan visi misi, langkah-langkah dan target yang akan di capai. Pepencanaan humas.

\section{Pentingnya Perencanaan Humas}

Ada banyak model di dalam perencanaan baik dilihat dari ruang lingkupnya, pendekatan, maupun waktunya. Di samping itu ada model morror image, curent image, multiple image, corporate image, dan copy writing ( teks line). Ada pula target setting, konfrehensif, costing dan ke efektifan biaya, dan ppbs (planning, programming, budgeting sistem) . tergantung dari sudut mana kita mengkajinya.

Dalam menejemen humas perencanaan biasanya ada di bagian awal atau sebelum menentukan segala sesuatu terkait menejemen maka perencanaan dilakukan sejak awal sebelum segala sesuatunya ditetapkan sebagaimana yang diungkapkan didalam buku menejemen humas, Perencanaan sebagai fungsi manajemen dilakukan pada tahap pertama sebelum melaksanakan kebijakan, program dan kegiatan. Perencanaan sebagai cetak biru (blu print) atas kebijakan, program dan kegiatan-kegiatan organisasi. ${ }^{4}$

Sebuah lembaga untuk menyampaikan pesannya kepada publik sangat membutuhkan media. Apalagi pesan-pesan prestasi yang baru di raihnya. Lembaga berusaha mencari alat, media apa yang tepat untuk menyampaikan pesan organisasinya. Banyak sekolah-sekolah sudah melakukan penyampaian pesannya baik melalui media massa, televisi, benner, dan lain sebagainya. Hal ini bertujuan untuk agar supaya lembaga mempertahankan citra baiknya di ranah publik.sebagaimana yang di sampaikan oleh Wardhani, dalam jurnalanya "Perencanaan Media Relations Di Sheraton Mustika Yogyakarta Untuk. Menciptakan Citra Positif ”, Organisasi membutuhkan media massa dalam penyampaian pesannya kekhalayak luas dan berharap publikasinya akan membangun persepsi atau Memberikan pesan, kesan, dan citra yang baik di mata masyarakat itu tidak mudah. Masyarakat mempunyai penilaian tersendiri bagi masing-masing lembaga. Persepsi mereka tidak sama. Tinggal bagaimana lembaga bisa memberikan pesan kesan dan citra yang baik yang bisa di terima secara umum.

Tiap lembaga pendidikan mempunyai menejemen dan salah satu fungsi menejemen adalah perencanaan. Perencanaan sebagai fungsi manajemen dilakukan pada tahap pertama sebelum melaksanakan kebijakan, program dan kegiatan.Perencanaan sebagai cetak biru (blu print) atas kebijakan, program dan kegiatan-kegiatan organisasi. Husnan (1984:7) menyatakan perencanaan

${ }^{4}$ Abdul Rahmat, MANAJEMEN HUMAS SEKOLAH, Media Akademi, 2016, I. 
merupakan proses dasar untuk menentukan sasaran yang ingin dicapai dan cara untuk mencapainya.

Selanjutnya Husnan (1984:8) menambahkan bahwa dengan menggunakan prosedur untuk pengambilan keputusan yang lebih rasional dan didasarkan pada fakta yang ada, maka perencanaan akan membantu para manajer dan organisasi untuk meminimumkan risiko dan ketidak-pastian. ${ }^{5}$

Organisasi atupun indifidu pasti memiliki rencana-rencana, baik itu sadar maupun tidak. Secara sadar, misalkan, seseorang mempunyai rencana membangun rumah, segala sesuatu yang berkaitan dengan rumah yang akan di bangun sudah di persiapkan dan ada gambaran sejak awal. Sesuatu yang berkaitan dengan rumah seperti bahan, alat, biaya dan lain sebagainya pasti di persiapkan sejak awal. Tidak mungkin seseorang yang punya rencana membangun rumah menafikan itu semua. Perencanaan yang seringkali tidak disadari seperti seseorang membuanyai aktifitas ketempat kerja, pada dasarnya mereka sudah mempunyai perencanaan.

Contoh lain adalah saya seorang mahasiswa unuja yang punya jadwal kuliyah tiap hari senin jam 09.00, maka pada hari itu atau hari sebelum itu saya sudah merencanakan untuk kuliyah. Segala sesuatunya harus saya persiapkan, baik itu buku, kendaraan, biaya dan lain sebagainya agar supaya ketika sampai di kampus saya sudah siap untuk mengikuti mata kuliyah.

Sebelum melangkah lebih jauh ke pembahasan inti dari jurnal ini maka alangkah lebih baiknya di ketahui apa itu perencanaan. Seperti apakah pendapat-pendapat ahli tentang perencanaan? Kita simak berikut ini.Dari pengertian perencanaan diatas maka dapat di simpulkan bahwa perencanaan itu di lakukan sedari awal sebab kegiatan tanpa perencanaan bisa jadi nanti tidak terarah.

Di dalam menejemen, perencanaan merupakan syarat yang harus dipenuhi, tanpa itu sebuah kegiatan akan mendapat kesulitan dan sebuah tujuan nanti tidak akan tercapai. Apalagi di dalam pendidikan sebuah lembaga pendidikan perencanaan merupakan syarat mutlak yang tidak bisa di tanggalkan. Perencanaan di tuntut adanya sebab ada pada ranah menejemen pendidikan,. Sebagai mana yang di ungkapkan oleh Dr. Manap Somantri, M.Pd dalam jurnal "PERENCANAAN PENDIDIKAN”, Perencanaan merupakan suatu proyeksi tentang apa yang harus dilaksanakan guna mencapai sasaran dan tujuan yang telah ditetapkan (Kaufman 1972; Hadikumoro 1980).

Sebagai suatu proyeksi, perencanaan memiliki unsur kegiatan mengidentifikasi, menginventarisasi dan menyeleksi kebutuhan berdasarkan skala prioritas, mengadakan spesifikasi yang lebih rinci mengenai hasil yang

${ }^{5}$ Laurensia Cahyani Rahayu, 'PERENCANAAN MEDIA RELATIONS DI SHERATON MUSTIKA YOGYAKARTA UNTUK MENCIPTAKAN CITRA', 1-15. 
akan dicapai, mengidentifikasi persyaratan atau kriteria untuk memenuhi setiap kebutuhan, serta mengidentifikasi kemungkinan alternatif, strategi, dan sasaran bagi pelaksanaannya ${ }^{6}$.

Sama juga dengan humas atau publik relatioan Bidang ini menempati bagian penting di dalam lembaga pendidikan atau bisa di katakan ruh lembaga. Humas mempunyai peran menjaga eksistensinya. Peran di dalam humas mempunya peran krusial dan berganda. Lembaga bisa berjalan di tempat atau mati jika humas tidak berjalan sebagaimana mestinya.

Peran ganda yang di jalankan oleh humas disamping dari sisi internal humas juga menjaga keseimbangan dengan masyarakat di luar lembaga sekolah. Ketika berhubungan dengan masyarakat inilah humas harus menggunakan seni, baik komunikasi, menjaga kemitraan, menjaga dan meningkatkan citra lembaga, menceritakan berita sukses, memperluas informasim menjalin ubungan dengan lembaga lain, membuka wilayah baru, dan lain sebagainya. Seni yang dimaksud di dalam humas inilah dinamakan model humas.

\section{Model Perencanaan Humas}

Sebelum melangkah lebih jauh ke pembehasaan inti perlu di ketahui dulu apa itu model dalam perencanaan humas. Model perencanaan yang di maksud sini adalah seperangkat pengetahuan yang perlu di ketahui, seperti apa, bagaimana, seberapakah kemampuan lembaga untuk menjangkau lembaga yang di inginkan/ dicita-citakan. Model perencanaan merupakan gambaran awal untuk melangkah ke tujuan.

Model disini yang dimaksud adalah langkah-langkah yang akan di tempuh oleh sebuah lembaga untuk merealisasikan rencananya. Langkah itu diantaranya penilaian situasi, mendefinisikan secara obyektif, definisi puplik, memilih teknik dan bahan, anggaran, dan laporan. Semua langkah itu akan membentuk suatu rentetan dalam program humas ${ }^{7}$

Dari semua rentetan langkah itu perlu kiranya untuk mendefinisikan dan memberi gambaran pengertian satu persatu yaitu yang Pertama, penilaian situasi merupakan penilaian situasi baik internal maupun eksternal. Internal maksudnya orang atau personal lembaga baik lieder, guru, karyawan, siswa. Eksternal maksudnya adalah masyarakat umum. Kedua, mendifinisikan secara obyektif. Hal ini dimaksudkan untuk mengetahui bagaimana lembaga di dalam maupun di luar menurut pandangan mereka. Langkah ini seorang pablik relation adalah hal penting karena untuk mengetahui dan menila lembaga haruh dari luar dan meminta pendapat mereka.

${ }^{6}$ Laurensia Cahyani Rahayu, 'PERENCANAAN MEDIA RELATIONS DI SHERATON MUSTIKA YOGYAKARTA UNTUK MENCIPTAKAN CITRA', 1-15.

${ }^{7}$ Rahayu. 
Perencanaan ialah menyeleksi dan menghubungkan pengetahuan, fakta, imajinasi, dan asumsi untuk masa yang akan datang dengan tujuan memvisualisasikan dan memformulasi hasil yang diinginkan, urutan kegiatan yang diperlukan, dan perilaku dalam batas-batas yang dapat diterima yang akan digunakan dalam penyelesaian. Perencanaan disini menekankan pada usaha menyeleksi dan menghubungkan sesuatu dengan kepentingan masa yang akan datang serta usaha untuk mencapainya. Apa wujud yang akan datang itu bagaimana usaha untuk mencapainya merupakan perencanaan (Hamzah, 2010).

Dalam beberapa kesempatan Grunig dan Hunt mengatakan tentang publik relation adalah bagian dari manajemen komunikasi antara organisasi dan publiknya. Komentar inilah yang dapat membantu untuk merumuskan empat model dalam praktek humas atau publik relation. Keempat model Publik relation bisa di sebut disini yaitu.

Pertama, Press agentry maksudnya adalah agen pemberitaan atau agen pers. Model ini dianggap sebagai bentuk yang paling awal dari praktek Publik relation. Praktisi humas atau publik relation dalam model ini selalu mencari kesempatan agar nama organisasi mereka muncul di media tanpa banyak melakukan penelitia dan riset tentang publik mereka. Juga Termasuk dalam model ini yaitu cara propaganda Komunikasi antara organisasi dan publik dijalankan secara satu arah tanpa diawali riset dengan tujuan membujuk publik untuk melakukan tindakan tertentu sesuai dengan apa yang diinginkan organisasi.

Kedua, Public information atau informasi publik. Model seperti ini bisa menggunakan pendekatan public be informed dimana informasi dikirim keluar oleh sebuah organisasi . namun sebuah model seperti ini praktisi publik relation atau humas lebih mengutamakan pendekatan persuasi dalam penyampaian informasi yang jujur dan akurat kepada halayak tanpa bertujuan memperalat publik. Hal ini Sama juga dengan model yang pertama, komunikasi dilakukan secara satu arah tanpa didahului riset mengenai informasi apa yang terbaik untuk langsung di komunikasikan kepada publik.

Ketiga, Two-way asymmetrical atau dua arah asimetris dalam kesempatan yang lain Hunt mengatakan bahwa model ini adalah karakter dari tipe Publik relatioanal atau humas yang dipraktekkan dari pertengahan tahun 1920 sampai 1950-an. Tentunya model asimetris gaya dua arah ini dianggap sebagai kerja persuasi ilmiah yang menggunakan metode riset ilmu sosialguna meningkatkan efektivitas persuasi dari pesan yang disampaikan. Persuasi ilmiah seperti ini biasa dianggap sebagai tujuan utama dan dijalankan melalui komunikasi dua arah dengan efek yang tidak seimbang. tersebut. 
Keempat, Two-way symmetrical atau dua arah simetris Karakter utama dari model ini adalah adanya kemauan kedua belah pihak untuk saling berdialog tidak hanya membujuk, namun juga mendengarkan, dan mempelajari, serta mengadaptasi perilaku dari pihakpihak yang berdialog. Model seperti ini ini mensyaratkan adanya komunikasi dua arah yang saling jujur dan memposisikan kedua pihak yang berkomunikasi dalam kedudukan yang seimbang. Komunikasi yang dijalin antara dua poros organisasi dan publik mempunyai tujuan untuk menciptakan pengertian mutu.

\section{Masalah-masalah humas di tiap-tiap lembaga}

Hubungan masyarakat atau publik relation yang ada di tiap -tiap lembaga di daerah kita hanya sebagai pelengkap struktural saja, walupun tidak kesemuanya. Humas Tidak berjalan sebagaimana fungsi ideal publik relaion. Publik relation sebenarnya merupakan fungsi lembaga memberikan informasi, sebagai cermin, sebagai penyambung antara lembaga dan publik/masyarakat.

Sebagai bagian dari menejemen pubik relation mempunyai langkah kerja, sistem, model dan strategi-strategi-strtegi tersendiri untuk menjaga citra dan memajukan organisasi. Namun tidak di lembaga secara umum di daerah kita. Kebanyakan mereka hanya berkutat pada struktur dan personal semata tidak hidup dan tidak berfungsi sebagi bagian dari menejemen. Tidak seperti bagian kurikulum yang di konsep, dirapatkan, mempunyai strategi, targerget dan tujuan, publik relation hanya ada struktur dan orangnya saja namun tidak dijalankan apalagi mempunyai menejemen. Seakan publik relation struktur yang di anak tirikan Atau lebih pasnya hanya sebagai pelengkap papan struktur saja.

Hal ini merupakan masalah kita bersama. Bagaimana bisa mempertahankan atau memajukan lembaga kalau hanya sebatas itu publik relation di fungsikan. Jangankan menetapkan target dan tujuan-tujuan lembaga untuk bersaing di ranah nasional maupun go internasional memfungsikan publikrelationnya saja hanya asal-asalan. Melihat masalah ini maka di rasa perlu untuk memfingsikan publik reltion sebagaimana mestinya. Menawarkan model-model publik relation untuk menunjang kemajuan lembaga merupakan sebuah keharusan.

Penulis mencoba untuk melakukan penelitian lewat metode literasi, dengan mencari penelitian yang sudah di lakukan di berbagai jurnal yang sudah ada dan di kombinasikan dengan imajinatif deskriptif. Hal ini dimaksudkan untuk memberikan gambaran bagi lembaga-lembaga yang merasa kebingungan menjalankan humas. 


\section{Tawaran bagi Lembaga Pendidikan Dalam Membangun Citra Yang Baik}

Lembaga pendidikan di probolinggo selama ini masih di percaya oleh masyarakat untuk di jadikan tempat sebagai pengembangan putra-putri mereka dalam mengembangkan potensinya. ada juga lembaga lain yang merepresentasikan tempat untuk mensejajarkan lembaga pendidikan di dalam mengasah potensi mereka, yaitu pondok pesantren. Namun demikian pondok pesantren juga menyediakan lembaga pendidikan baik formal maupun non formal. Lembaga pendidikan formal sama halnya dengan pendidikan pada umumnya di luar. Lembaga non formal inilah yang di kelola pesantren hampir sejajar dengan lembaga pendidikan pada umumnya.

Masing-masing lembaga tersebut tentunya ingin menjaga citra dan mengembangkannya sesuai kreteria dan pengetahuan mereka. Caranya dengan gaya yang mereka miliki. Seperti menampilkan prestasi yang sudah di raihnya, menawarkan spp yang murah atau bahkan di gratiskan ${ }^{8}$. Mereka tidak memakai menejemen publik relation. Mungkin mereka tidak kenal atau tidak mengetahui apa itu publik relation Cuma mereka mengenal dan memakai nama humas atau hubungan masyarakat. Maka dari itu perlu mengetahui apa itu publik relation.

Adapun publik relation merupakan sebagai jembatan atau penyambung antara lembaga dan publik. Maka dari itu sebagai penyambung ia di harapkan untuk memberikan saran dan masukan kepada pimpinan dalam segala kebijakan, segala tujuan dan filofofi lembaga agar tercipta hubungan yang saling menguntungkan antara lembaga dan masyarakat atau publik. Publik relation di tuntun untuk selalu membantu dan memfasilitasi lembaga untuk melakukan perubahan sesuai dengan perubahan yang terjadi di masyarakat. ${ }^{9}$

Sebagaimana yang sudah di jelaskan tentang model-model pulik relation diatas maka perlu juga di ketahui efek-efek dari peran publik relation itu sendiri. Diantara efek yang di timbulkan oleh publik relation adalah memberikan dan menjaga citra lembaga. Sebab masyarakat secara tidak sadar sudah memantau dan menilai lembaga pendidikan. Tujuan mereka melakukan itu tiada lain adalah untuk menyeleksi nanti dimana akan meletakkan putraputrinya. Citra adalah pengetabuan mengenai kita dan sikap-sikap terhadap kita yang mempunyai kelompok-kelompok yang berbeda. Hal ini menunjukkan bahwa citra adalah bagaimana dunia sekeliling kita yang memandang kita ${ }^{10}$.

${ }^{8}$ Hasan Baharun, 'Peningkatan Kompetensi Guru Melalui Sistem Kepemimpinan Kepala Madrasah', At-Tajdid: Jurnal Ilmu Tarbiyah, 6.1 (2017), 1-25. Relations'.

${ }^{9}$ Ike Devi Sulistyaningtyas, 'Riset Sebagai Ujung Tombak Keberhasilan Program Public

${ }^{10}$ Fitri Arfilia and others, 'PROSES PUBLIC RELATIONS DALAM MENGELOLA MEDIA SOSIAL TWITTER The Process of Public Relations in Managing Social 
Sebagai fungsi menejemen publik relation di tuntut untuk mempunyai peran penting bagi lembaga untuk membentuk citra. Tujuannya mengetahui apa yag dilakukan untuk lembaga dan mengetahui harapan masyarakat atau publiknya. Dalam jurnal "Citra Yang Ditampilkan Perusahaan Dalam Press Release " Sarah Rogatianni Artati Gultom menyebutkan bahwa Frank Jefkins mengatakan citra merupakam kesan seorang ataupun individu mengenai sesuatu yang timbul sebagai hasil pengetahuan dan pengalamannya.

Citra yaitu kesan yang diperoleh berdasarkan pengetahuan, pengertian dan pengalaman sesorang mengenai fakta-fakta atau kenyataan. Frank Jefkins mengklasifikasikan citra menjadi lima macam, yaitu:

1. mirror image/ citra bayangan, adalah citra yang sudah diyakini oleh lembaga atau perusahaan bersangkutan yang selalu merasa dalam posisi selalu baik tanpa mengacuhkan kesan-kesan orang luar lembaga.

2. current image/ citra yang berlaku adalah citra yang telah dianut oleh beberapa pihak diluar atau publik mengenai suatu lembaga.

3. wish image/ citra harapan adalah citra yang sdah diinginkan oleh pihak lembaga.

4. corporate image citra perusahaan adalah citra yang muncul dari suatu lembaga secara menyeluruh, tidak hanya dari citra produk saja dan pelayanannya tetapi juga mencakup sejarahnya atau riwayat hidup perusahaannya,kesediaannya turut memikul tanggung jawab sosial, mau berkomitmen mengadakan riset, prinsip kerja dan keberhasilan lembaga, menjalin hubungan yang baik dengan stakeholders, dan sebagainya.

5. multiple image/ Citra majemuk yaitu citra yang sudah muncul dari beberapa jumlah individu, beberapa cabang atau perwakilan dari lembaga atau organisasi tetapi belum tentu sama dengan citra lembaga atau organisasi secara keseluruhan.

Lain halnya yang di ungkapkan oleh siswanto Sutojo. Dia mengungkapkan tentang tiga jenis citra yang dapat diutamakan lembaga atau organisasi, yaitu:

1. eksklusif. artinya citra yang di utamakan sebab memiliki kemampuan untuk menyuguhkan berbagai macam manfaat unggulan kepada publik maupun pelanggan.

2. Citra inovatif. artinya sebuah citra yang sangat di utamakan dan menonjol karena lembaga tersebut menyuguhkan produk baru yang desainnya tidak dimiliki oleh pruduk produk sejenis yang beredar di luaran.

Media Twitter (Descriptive Study on Program of Public Relations @infobdg Period Mei 2015)', 2.3 (2015), 4337-44. 
3. Citra murah meriah. artinya citra yang utamakan oleh lembaga atau organisasi karena menyuguhkan produk dengan mutu yangbagus namun memberikan harganya murah.

Riset yang dilakukan oleh Sonap Somatri dalam penelitiannya di PLN cabang kota kabpaten bandar lampung terkait dengan membangun citra perusabaan yaitu menonjolkan profesionalnya. Dalam jurnalnya ia menyebutkan, "Peranan bumas di PT. PLN cabang kota Bandar Lampung mampu meningkatkan citra perusabaan dengan menyugugubkan pelayanan secara profesional. Berdasarkan teori tentang 'citra' dikatakan babwa citra itu adalah serangkaian pengetabuan-pengetahuan, beberapa pengertian dan perilaku-perilaku komunikasi yang sudah direkam dalam pengalaman yang sudah dilakukan, emosi, dan penilaian-penilaian yang ditata oleh individu sebingga diyakini kebenarannya".

Dalam instansi pemerintah yang dirancang oleh kementrian aparatur negara dan reformasi birokrasi republik indonesia tabun 2011 disebutkan mengenai pedoman misi praktisi publik relation adalab membangun citra, reputasi dan nama baik prkatisi publik relation sebagai bagian dari aparatur negara, membentuk. opini publik, menampung dan mengelola pesan serta aspirasi masyarakat, mengklarifikasi data dan informasi yang sudab berkembang di masyarakat serta mampu mensosialisasikan beberapa program dan kebijakan dari pemerintah. ${ }^{12}$

Disamping itu juga ada peran di luar lembaga atau organisasi itu sendiri dalam membangun citra baik nya yaitu pers. Oleh karena itu sebuah lembaga dituntut pula membangun relasi dan hubungan baik dengan media, baik itu media massa maupun media elektronik seperti radio dan telivisi. Peran puplik relation sangat menentukan dalam hal ini karena disamping menjalin hubungan dengan pihak internal lembaga, publik relation juga harus membangun hubungan dengan pihak eksternal yaitu pers.

Untuk mengetahui bagaimana citra organisasi di mata publik melalui pemberitaan di media massa, maka riset menjadi "dewa penolong" untuk memperoleh hasil gambaran mengenai citra organisasi melalui analisis isi (content analysis researcb). ${ }^{13}$

Publik relation tidak hanya menjalin hubungan baik dengan pihak pers tetapi juga dintuntut menjalin hubungan dengan pihak lain yaitu stakeholdersstakeholder yang ada di masyarakat sebagaimana yang sudah diungkapkan oleh anggoro.

Terbaru, untuk meningkatkatkan dan menjaga citra lembaga di upayakan untuk memeiliki tim cyber. Tren cyber pada publik relations saat ini tidak hanaya mengubah gaya hidup penggunanya tetapi telah mengubaha cara perusahaan berpromosi utanamnya di dalam berkomunikasi.gubah gaya

\footnotetext{
${ }^{11}$ Somantri.

${ }^{12}$ Dian Purworini, 'Model Informasi Publik Di Era Media Sosial : Kajian Grounded Teori Di Pemda Sukoharjo', KomuniTi, 6.1 (2014), 3-14.

${ }^{13}$ Sulistyaningtyas.
} 
hidup sebagian penggunanya tetapi juga telah mengubah cara perusahaan berpromosi terutama dalam berkomunikasi, hal ini memberikan peluang bear bagi lembaga untuk menggunakan cyber publik relation sebagai media pilihan dan alternatif di dalam membangun dan menjaga citra lembaga atau brand awarenes.

Itulah sampai beberapa gambaran tentang tawaran-tawaran membangun citra publik relation atau kehumasan. Jadi sangat komplek tentang publik relation tidak hanya melulu komunikasinya kepada pihak internal naupun eksternal namun juga harus memanfaatkan tekhnologitehnologi yang selalu berubah dan di tuntut untuk mengikuti perkenmbangannya. Keberhasilan public relations dalam membentuk atau mempertahankan citra organisasi, merupakan keberhasilan dari sederet rangkaian proses yang kompleks dan cukup panjang. ${ }^{14}$

Adalagi yang tidak bisa di lupakan yaitu pelayanan yang di berikan kepada pengguna atau pelanggan, merupakan cara untuk menjaga citra perusahaan hal ini dimaksudkan untuk menjaga saling pengertian dan menjaga hubungan. ${ }^{15}$

\section{Perencanaan Humas Dan Usaha Membangun Citra Lembaga Yang Unggul}

Humas/ publik relation mempunyai peran sentral di sebuah lembaga pendidikan. Tidak hanya sebagai pelengkap saja, menurut pendangan lembaga pendidikan kebanyakan, namun sebagai penengah antara lembaga dengan internanya dan lembaga dengan publiknya. Peran ganda inilah yang dimainkan oleh pemegang tugas kehumasan.

Disamping itu juga tugas kehumasan di tuntut untuk selalu membangun citra lembaga dengan baik. Maka dari itu kehumasan/publik relation harus mempunyai strategi dan cara-cara jitu untuk melaksanakan tugas itu semua. Langkah awal biasanya didalam lembaga yang mahir dalam menejemen adalah membuat perencanaan dengan se matang mungkin. Selanjutnya menggunakan fungsi menejemen secara baik. Perencanaan merupakan langkah awal dari menejemen. untuk memuluskan apa yang di cita-citakan oleh lembaga maka dirasa perlu untuk mebuat rencana se bagus dan sedetel mungkin.

Biasanya di setiap organisasi baik itu lembaga, perusahaan, negara, maupun badan-badan internasional membuat rencana sebagai langkah awal untuk mencapai apa yang di cita-citakan dan meraih tujuan adalah keharusan. di dalam dimensinya terdapat ruang lingkup perencanaan. Dimensi waktu dalam perencanaan misalkan ada perencanaan jangka panjang( long term

\footnotetext{
${ }^{14}$ Sulistyaningtyas.

${ }^{15} \mathrm{Ibrahim}$ Besar.
} 
planning), biasanya berjangka waktu 10 tahun keatas, perencanaan jangka menengah ( medium term planning), perencanaan ini biasanya berjangka waktu 3 sampai 8 tahun, dan perencanaan jangka pendek ( short term planning), perencanaan yang jangka waktunya kurang lebih setahun. Dimensi spasial ( terkait dengan ruang dan batasan wilayah), ada perencanaan nasional, regional, perencanaan tata ruang.

Dimensi tingkat teknis perenanaan ada makro, mikro, sektoral, kawasan, dan perencanaan proyek. Nah, inti dari sebuah perencanaan adalah usaha merancang dan memilih pada waktu sekarang untuk suatu yag ingin di wujudkan dimasa yang akan datang (choosing our decired future today).

Perencanaan di lembaga pendidikan utanmanya dalam kehamasan adalah merancang apa yang ingin di capai oleh lembaga. Dan tugas humas adalah mebungkus dan memasarkanya ke ranah publik. Disinilah inti peran humas supaya citra dari lembaga terbangun sebagus dan sebaik mungkin.

Ada beberapa tugas humas yang akan di ungkap disni dinatanya yaitu:

1. mirror image/ citra bayangan, adalah citra yang sudah diyakini oleh lembaga atau perusahaan bersangkutan yang selalu merasa dalam posisi selalu baik tanpa mengacuhkan kesan-kesan orang luar lembaga.

2. current image/ citra yang berlaku adalah citra yang telah dianut oleh beberapa pihak diluar atau publik mengenai suatu lembaga.

3. wish image/ citra harapan adalah citra yang sdah diinginkan oleh pihak lembaga.

4. corporate image citra perusahaan adalah citra yang muncul dari suatu lembaga secara menyeluruh, tidak hanya dari citra produk saja dan pelayanannya tetapi juga mencakup sejarahnya atau riwayat hidup perusahaannya,kesediaannya turut memikul tanggung jawab sosial, mau berkomitmen mengadakan riset, prinsip kerja dan keberhasilan lembaga, menjalin hubungan yang baik dengan stakeholders, dan sebagainya.

5. multiple image/ Citra majemuk yaitu citra yang sudah muncul dari beberapa jumlah individu, beberapa cabang atau perwakilan dari lembaga atau organisasi tetapi belum tentu sama dengan citra lembaga atau organisasi secara keseluruhan.

Dari peran centaral kehumasan dalam membangun citra inilah lembaga bisa bersaing baik dalam lingkup regional maupun tingkat nasional bahkan nanti bisa keranah internasional. Sebab lembaga pendidikan adalah organisasi yang menawarkan sebuah jasa pendidikan yang mengharapkan kepercayaan publik secara kontinu dan berkelanjutan bahkan selama peradaban manusia berlangsung di dunia maka pendidikan adalah dasarnya. Dan tugas untuk menanamkan kepercayaan dari jasa yang di tawarkan adalah tugas humas. 


\section{Daftar Pustaka}

Arfilia, Fitri, Martha Tri Lestari, Dini Salmiyah Fithrah Ali, Ilmu Komunikasi, Fakultas Komunikasi dan Bisnis, and Universitas Telkom, 'PROSES PUBLIC RELATIONS DALAM MENGELOLA MEDIA SOSIAL TWITTER The Process of Public Relations in Managing Social Media Twitter (Descriptive Study on Program of Public Relations @infobdg Period Mei 2015)', 2 (2015), 4337-44

Baharun, Hasan, 'Peningkatan Kompetensi Guru Melalui Sistem Kepemimpinan Kepala Madrasah', At-Tajdid: Jurnal Ilmu Tarbiyah, 6 (2017), 1-25

Baharun, Hasan, and Syafiqiyah Adhimiy, 'Curriculum Development Through Creative Lesson Plan', Cendekia: Jurnal Kependidikan Dan Kemasyarakatan, 16 (2018), 41-62

Hasan Baharun, Zamroni, Manajemen Mutu Pendidikan: Ikhtiar Dalam Meningkatkan Mutu Pendidikan Madrasah Melalui Pendekatan Balanced Scorecard (Tulungagung: Akademia Pustaka, 2017)

Ibrahim Besar, 'PERAN PUBLIC RELATIONS DALAM MEMBANGUN CITRA', 2016, 367-73

Lindenmann, Walter K, 'Public Relations Research for Planning and Evaluation Resource', Institute for Public Relations, 2006, 1-33

Purworini, Dian, 'Model Informasi Publik Di Era Media Sosial: Kajian Grounded Teori Di Pemda Sukoharjo', KomuniTi, 6 (2014), 3-14

Rahayu, Laurensia Cahyani, 'PERENCANAAN MEDIA RELATIONS DI SHERATON MUSTIKA YOGYAKARTA UNTUK MENCIPTAKAN CITRA', 1-15

Rahmat, Abdul, MANAJEMEN HUMAS SEKOLAH, Media Akademi, 2016, 01

Somantri, Manap, Perencanaan Pendidikan, 2014

Sulistyaningtyas, Ike Devi, 'Riset Sebagai Ujung Tombak Keberhasilan Program Public Relations' 
134 | TADBIR : Jurnal Studi Manajemen Pendidikan, Vol. 2, No. 2, Desember 2018

This page belongs to the TADBIR : Jurnal Studi Manajemen Pendidikan

TADBIR : Jurnal Studi Manajemen Pendidikan vol. 2 , no. 2, Desember 2018

STAIN Curup - Bengkulu | p-ISSN 2580-3581; e-ISSN 2580-5037 